\title{
Magnetic resonance imaging findings of disc-related epidural cysts in nonsurgical and postoperative microdiscectomy patients*
}

Achados de ressonância magnética em cistos epidurais de origem discal em pacientes não operados e após microdiscectomia

\author{
Marcelo Novelino Simão ${ }^{1}$, Clyde A. Helms ${ }^{2}$, William J. Richardson ${ }^{3}$
}

\begin{abstract}
Objective: To demonstrate five discal cysts with detailed magnetic resonance imaging findings in nonsurgical and following postoperative microdiscectomy. Materials and Methods: Five discal cysts in four patients who underwent magnetic resonance imaging were found through a search in our database and referral from a single orthopedic spine surgeon. Computed tomography in two cases and computed tomography discography in one case were also performed. Results: Five discal cysts were present in four patients. Three patients had no history of previous lumbar surgery and the other patient presented with two discal cysts and recurrent symptoms after partial laminectomy and microdiscectomy. All were oval shaped and seated in the anterior epidural space. Four were ventrolateral, and the other one was centrally positioned in the anterior spinal canal. One showed continuity with the central disc following discography. Three were surgically removed. Conclusion: Magnetic resonance imaging can easily depict an epidural cyst and the diagnosis of a discal cyst should be raised when an homogeneous ventrolateral epidural cyst contiguous to a mild degenerated disc is identified.
\end{abstract}

Keywords: Magnetic resonance imaging; Lumbar spine; Discal cyst; Extradural cyst.

Resumo Objetivo: Demonstrar os achados de imagem em cinco casos de cisto discal em pacientes sem cirurgia prévia e após microdiscectomia. Materiais e Métodos: Cinco cistos discais em quatro pacientes submetidos a exames de ressonância magnética foram identificados após procura em nossos sistemas de dados e por referência de um cirurgião ortopédico especialista em coluna. Exames de tomografia computadorizada também estavam disponíveis em dois casos e discografia por tomografia computadorizada em um caso. Resultados: Três pacientes não tinham história prévia de cirurgia lombar e o outro paciente, que tinha dois cistos discais, apresentava recorrência dos sintomas após laminectomia parcial e microdiscectomia. Todos os cistos mostravam aspecto ovalado e estavam localizados no espaço epidural anterior, sendo quatro ventrolaterais, e o outro estava posicionado na região central do espaço epidural anterior. A discografia por tomografia computadorizada, disponível em um caso, demonstrou continuidade do cisto com o disco. Três foram submetidos a ressecção cirúrgica. Conclusão: A ressonância magnética pode facilmente identificar um cisto epidural e o diagnóstico de cisto discal deve ser considerado quando uma imagem cística homogênea, localizada no espaço epidural anterior, ventrolateral, e em contato com um disco parcialmente degenerado for identificada.

Unitermos: Ressonância magnética; Coluna lombar; Cisto discal; Cisto epidural.

Simão MN, Helms CA, Richardson WJ. Magnetic resonance imaging findings of disc-related epidural cysts in nonsurgical and postoperative microdiscectomy patients. Radiol Bras. 2012 Jul/Ago;45(4):205-209.

\section{INTRODUCTION}

Lumbar radiculopathy is a very common condition usually related to degenerative disease of the spine and herniated discs. Several other conditions have been

* Study developed at Central de Diagnóstico Ribeirão Preto (Cedirp), Ribeirão Preto, SP, Brazil, and Duke University Medical Center, Durham, NC, USA.

1. PhD, MD, Physician at Central de Diagnóstico Ribeirão Preto (Cedirp), Ribeirão Preto, SP, Brazil.

2. MD, Professor of Radiology, Chairman of Musculoskeletal Section, Duke University Medical Center, Durham, NC, USA.

3. MD, Professor of Orthopedic Surgery, Chief of Spine Surgery Section, Duke University Medical Center, Durham, NC, USA. associated with radiculopathy, among them epidural cysts $^{(\mathbf{1 , 2})}$. The most common locations are the facet joint and the ligamentum flavum $^{(3)}$. A case of a ganglion cyst of the lumbar spine annulus fibrosus compressing a nerve root was reported by Kornberg in $1995^{(4)}$. A cyst that communicates with the intervertebral disc is called a "discal cyst" and is very rarely found, being first de-

Corresponding author: Dr. Marcelo N. Simão. Rua Manoel Achê, 921, ap. 172, Jardim Irajá. Ribeirão Preto, SP, Brazil, 14020-590. E-mail: marcelo_simao@hotmail.com

Received January 13, 2012. Accepted after revision June 15, 2012. scribed by Kono et al. in $1999^{(\mathbf{5})}$. A more complete description was made by Chiba et al. in $2001^{(\mathbf{6})}$. The pathogenesis of discal cysts is unclear, with several suggested hypotheses including a mechanism similar to that of meniscal cyst of the knee and synovial cyst of the facet ${ }^{(5)}$; hematoma resorption $^{(6)}$ or that such cysts are ganglion cysts that derive from the annulus fibrosus ${ }^{(7)}$ or the posterior longitudinal ligament; findings of residual disc tissue in the cyst wall ${ }^{(\mathbf{1})}$ and discal cyst followed by a herniated $\operatorname{disc}^{(\mathbf{8})}$ supporting the theory of focal degeneration. Cyst-like fluid collections commu- 
nicating with the annulus fibrosus have also been described as a rare complication of microdiscectomy in patients with recurrence of radicular pain ${ }^{(\mathbf{9 , 1 0})}$.

The authors' purpose is to demonstrate five discal cysts with detailed magnetic resonance imaging (MRI) findings, including two cases of cysts which appeared following microdiscectomy.

\section{MATERIALS AND METHODS}

The subjects of our study consisted of five discal cysts found at MRI in four patients identified after a search in the authors' institution database and referral from a single orthopedic spine surgeon. All images were obtained with a $1.5 \mathrm{~T}$ scanner (Signa Excite or HDx; GE Healthcare, Milwaukee, WI, USA) and the protocol included sagittal T1-weighted sequences (TR 550/TE 14) and T2-weighted sequences (TR 4000/TE 60), $26 \times 26 \mathrm{~cm}$ field of view, $4.0 \mathrm{~mm}$ slice thickness with $1.0 \mathrm{~mm} \mathrm{sec}$ tion gap, matrix $256 \times 256$ and axial T2weighted sequences (TR 4000/TE 70-90), $16 \times 16 \mathrm{~cm}$ field of view and $4.0 \mathrm{~mm}$ slice thickness with $0.4-1.0 \mathrm{~mm}$ section gap continuous or angulated in discal spaces and matrix $256 \times 256$. Also, computed tomography (CT) was performed in two cases and CT discography (CTD) in one case. A two-year imaging follow-up was available for one patient with clinical follow-up. Surgical report was available for three of the cases.

\section{RESULTS}

A summary of clinical and imaging findings is shown on Table 1.

The present study includes data regarding five discal cysts in four patients (three men and one woman, mean age 29.7 years, age range 21-36 years). Three patients had no previous history of lumbar surgery at the level of the discal cyst and presented with clinical symptoms of lumbar pain and radiculopathy. The other patient presented with two discal cysts and recurrent symptoms after partial laminectomy and microdiscectomy performed at both levels twelve weeks before symptoms recurrence.

There were three cysts at L4-L5 level and two at L5-S1 level. All cysts presented
Table 1 Summary of patients' clinical and imaging findings.

\begin{tabular}{|c|c|c|c|c|c|}
\hline & Case 1 & Case 2 & Case 3 & Case 4 & Case 4 \\
\hline Age (years) & 28 & 34 & 36 & 21 & 21 \\
\hline Sex & Male & Male & Female & Male & Male \\
\hline $\begin{array}{l}\text { Lumbar pain/ } \\
\text { radiculopathy }\end{array}$ & Yes & Yes & Yes & Yes & Yes \\
\hline Level & L4-L5 & L5-S1 & L4-L5 & L4-L5 & L5-S1 \\
\hline Disc degeneration & Mild & Mild & Mild & Mild & Mild \\
\hline $\begin{array}{l}\text { Adjacent disc } \\
\text { protrusion }\end{array}$ & Yes & No & Yes & Yes & Yes \\
\hline $\begin{array}{l}\text { Communication } \\
\text { annulus fibrosus }\end{array}$ & Yes (MRI) & Yes (MRI/CTD) & Yes (MRI) & Yes (MRI) & Yes (MRI) \\
\hline Signal intensity & $\begin{array}{l}\text { High T2 } \\
\text { Low T1 }\end{array}$ & $\begin{array}{l}\text { High T2 } \\
\text { Low T1 }\end{array}$ & $\begin{array}{l}\text { High T2 } \\
\text { Low T1 }\end{array}$ & $\begin{array}{l}\text { High T2 } \\
\text { Low T1 }\end{array}$ & $\begin{array}{l}\text { High T2 } \\
\text { Low T1 }\end{array}$ \\
\hline Epidural position & Central & $\begin{array}{c}\text { Left } \\
\text { ventrolateral }\end{array}$ & $\begin{array}{c}\text { Right } \\
\text { ventrolateral }\end{array}$ & $\begin{array}{c}\text { Left } \\
\text { ventrolateral }\end{array}$ & $\begin{array}{c}\text { Bilateral } \\
\text { ventrolateral }\end{array}$ \\
\hline $\begin{array}{l}\text { Previous surgery } \\
\text { at level }\end{array}$ & No & No & No & Yes & Yes \\
\hline Evolution & $\begin{array}{l}\text { Clinical } \\
\text { follow-up }\end{array}$ & Unknown & Surgery & Surgery & Surgery \\
\hline
\end{tabular}

CTD, computed tomography discography; MRI, magnetic resonance imaging. homogeneous, low-to-moderate signal intensity on T1-weighted images and high signal intensity on T2-weighted images, and were oval shaped, being seated in the anterior epidural space. Four cysts were ventrolaterally located, one to the right, two to the left, and one with bilateral extension. The other one was centrally positioned in the anterior spinal canal. No MRI sign of intracystic hemorrhage or bone erosion was observed. The adjacent disc presented mild signs of degeneration in all cases.

A communication with the annulus fibrosus was suggested in all cases based on the MRI T2-weighted images (Figure 1) and in one case was confirmed by CT discography (Figure 2). In two cases, CT images were also available and showed epidural tissue slightly hypodense to the disc (Figure 3).

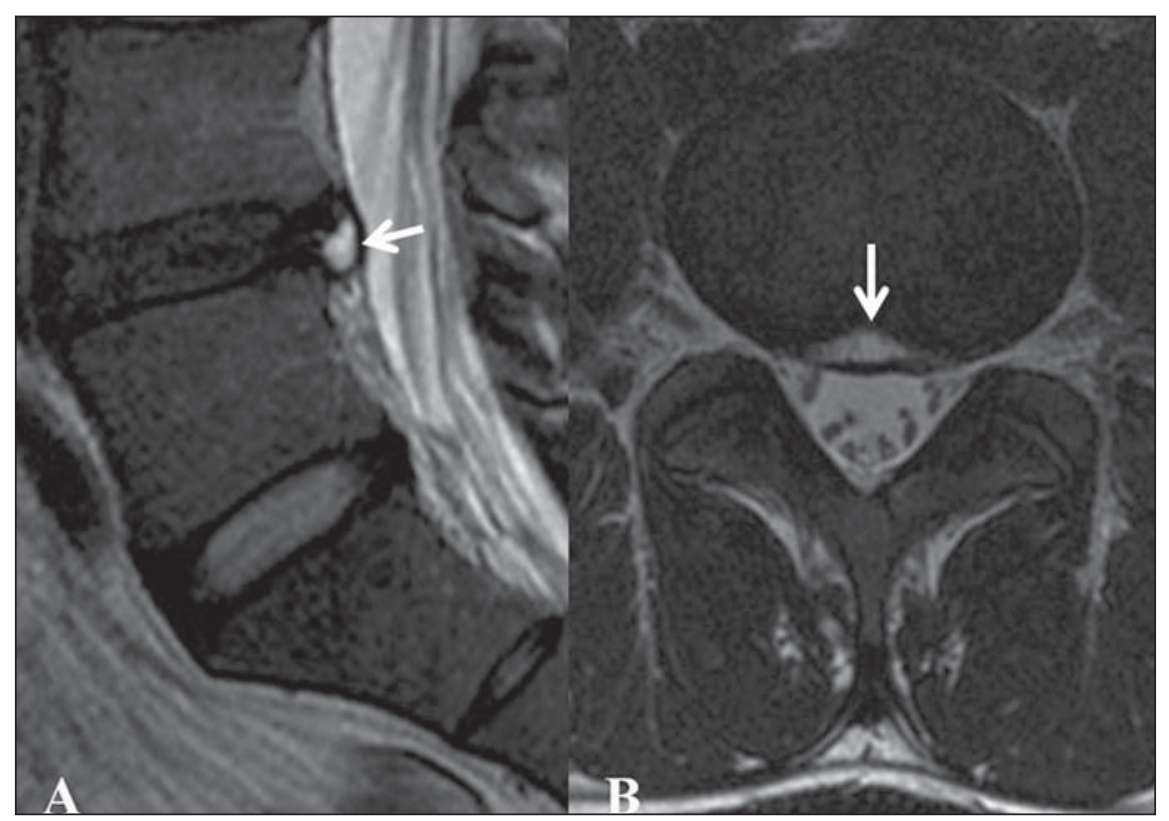

Figure 1. Sagittal MRI T2-weighted (A) and axial MRI T2-weighted (B) images of case 3 showing a highsignal oval shaped cyst in the anterior epidural space, centrally located in contiguity with a disrupted annulus fibrosus (arrows). 


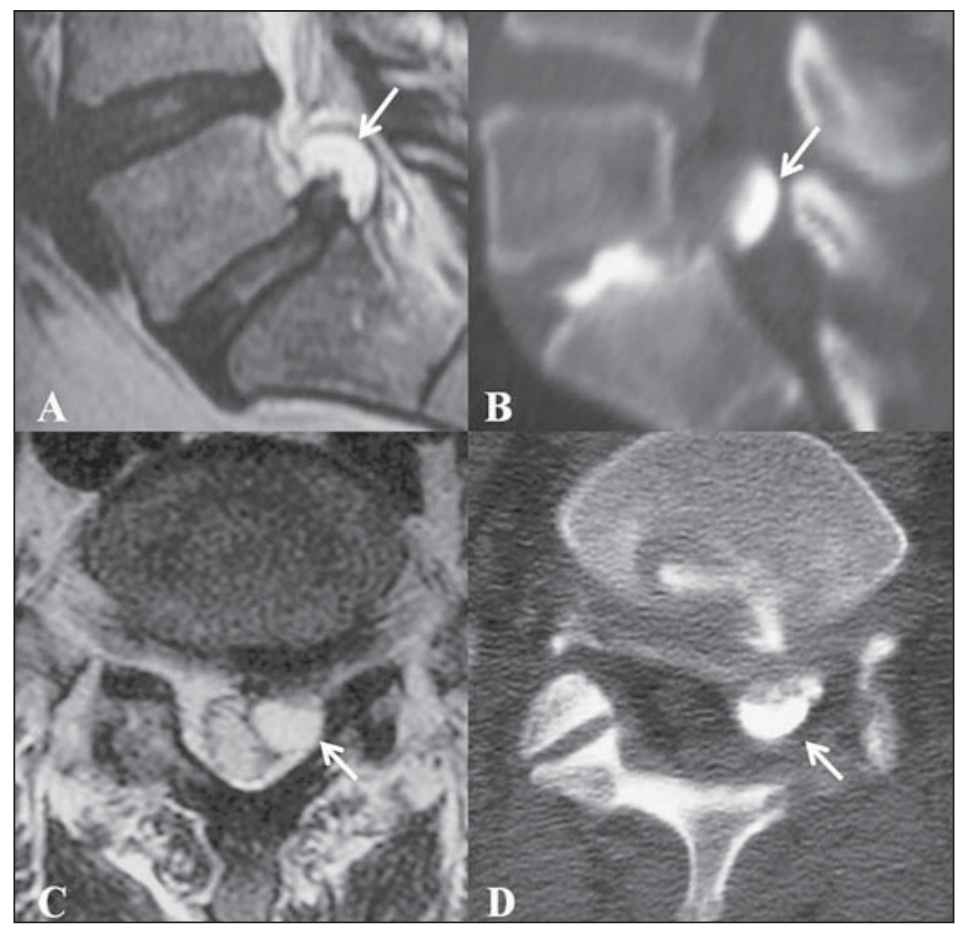

Figure 2. Sagittal MRI T2-weighted and reformatted CTD images (A,B), axial MRI T2-weighted and CTD images (C,D) of case 1 showing left-sided, ventrolateral cyst in epidural space communicating with the disc and filled by contrast medium on CTD image (arrows). Courtesy from Dr. Xavier Stump, São Paulo, Brazil.

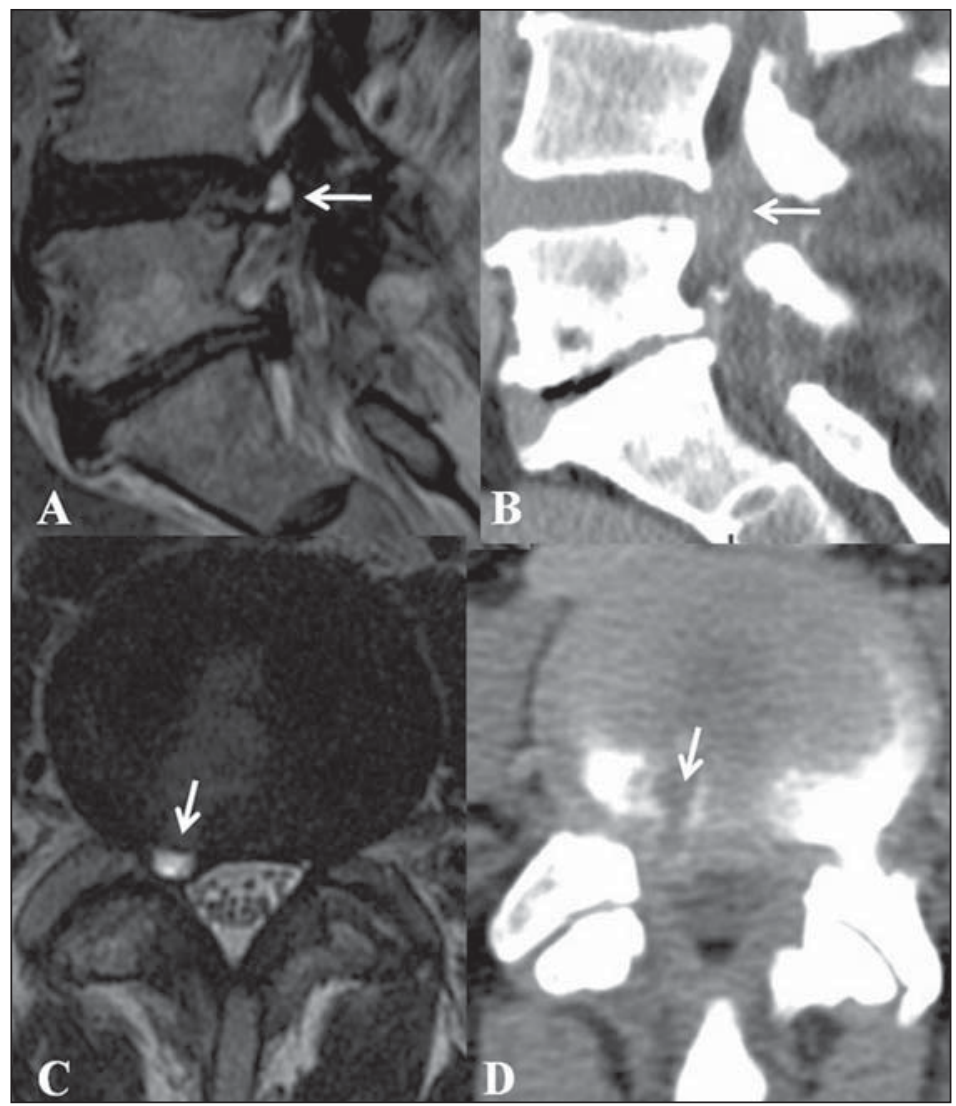

Figure 3. Sagittal MRI T2-weighted and reformatted CT images (A,B) axial T2-weighted and CT images (C,D) of case 2 showing a right-sided cyst in ventrolateral space (arrows) hyperintense on T2-weighted images and slightly hypodense related to disc at CT, surgically proved to be a discal cyst.
One patient (case 1) had no available follow-up data. Case 3 was conservatively treated and had unchanged cyst findings at one-year MRI follow-up, and two years of unchanged tissue with epidural mass effect since the first CT examination.

Surgery was performed in patient 2 and findings included a discal cyst in the extradural space with a distinct fibrous capsule and containing slightly bloody serous fluid (Figure 3).

Patient 4 had previously undergone lumbar microdiscectomy at L4-L5 and L5$\mathrm{S} 1$ levels, and 12 weeks later presented recurrent lumbar pain related to postsurgical pseudocysts at both levels (Figure 4), and was surgically treated in another institution.

\section{DISCUSSION}

Lumbar pain and radiculopathy are very common clinical conditions and MRI is performed to rule out the presence of a herniated disc which is probably the most common reason for lumbar spine investigations. Epidural cysts may be clinically indistinguishable from a herniated disc, but constitute a less common cause of radiculopathy ${ }^{(6)}$. Differential diagnoses include discal cysts, perineural cysts, facet synovial cysts, ganglion cysts of the posterior longitudinal ligament or ligamentum flavum, cystic nerve sheath tumors, extradural arachnoid cysts, enteric or dermoid cysts or other cyst-like conditions such as epidural varices and premembranous hematomas ${ }^{(5-7)}$. In a review of uncommon presentations of degenerative disc disease at MRI in eight patients, Eerens et al. ${ }^{(11)}$ have found one case of discal cyst.

The ventrolateral epidural space could also be occupied by an extruded disc fragment, just like a discal cyst. Usually, a disc fragment is easily differentiated from a discal cyst at MRI due to signal characteristics and enhancement pattern. A disc fragment has low signal intensity on T1- and T2-weighted images, and a cystic mass is homogeneous and isointense to cerebrospinal fluid, although it may have some heterogeneous components due to protein contents. A discal fragment rarely presents myxoid degeneration of disc material with diffuse apoptotic change and may cause troubles in the diagnosis due to the high 


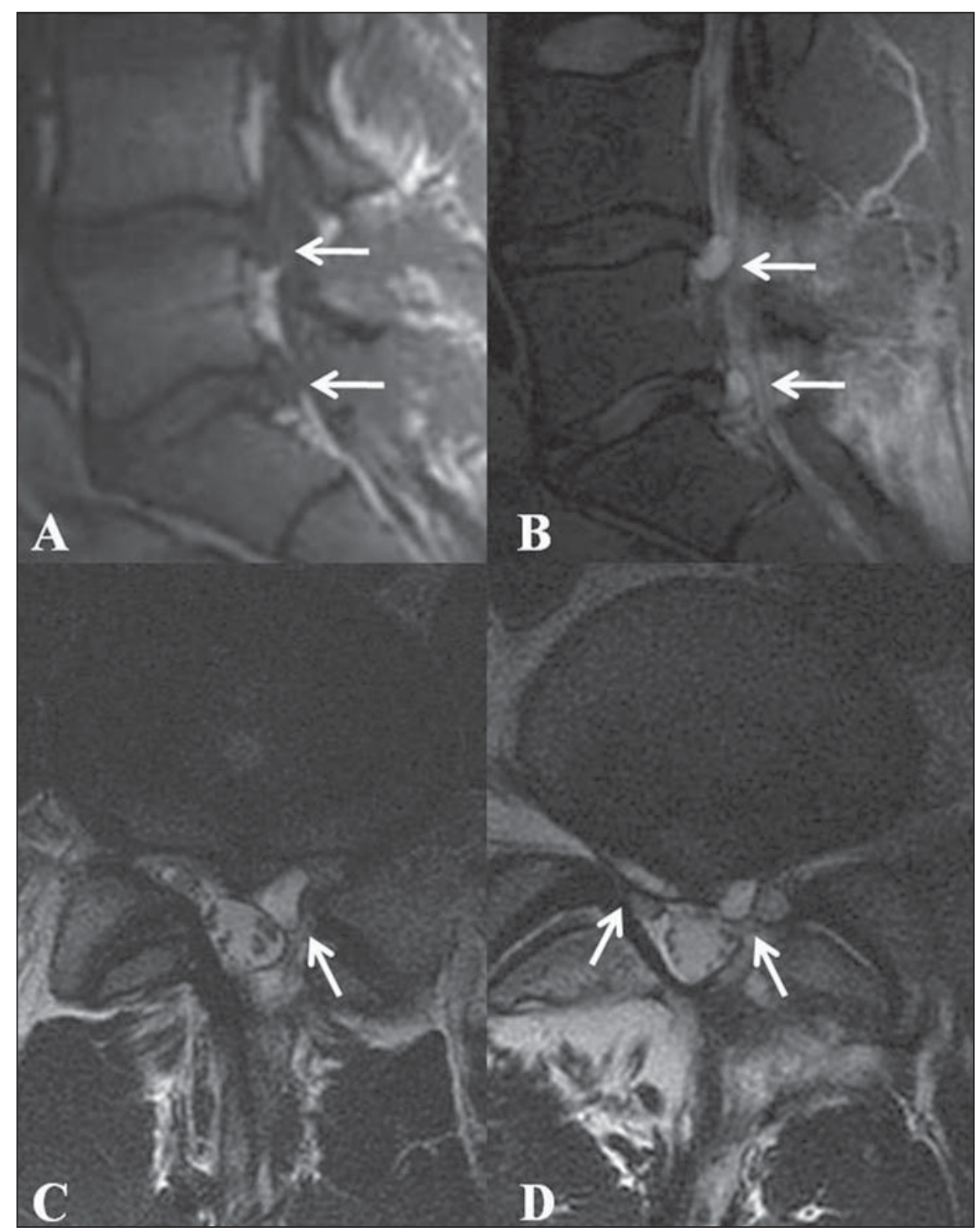

Figure 4. Sagittal MRI T1- and T2-weighted images (A,B), axial MRI T2-weighted image at L4-L5 level (C) and L5-S1 level of case 4 showing double postsurgical pseudocysts related to discs at both levels (white arrows).

signal intensity on T2-weighted images ${ }^{(\mathbf{1 2})}$. Although not essential and not available in any case of our series, post-contrast images features include a nonenhancing disc fragment surrounded by thick granulation tissue in extruded hernia ${ }^{(\mathbf{1 3})}$, while contrastenhanced MRI delineates a thin rim enhancement in discal cyst ${ }^{(\mathbf{5})}$, which contributes to elucidate the differential diagnosis..

The diagnosis of discal cyst may be achieved with basis on MRI findings of a ventrolateral homogeneous epidural cyst hypointense on T1- and hyperintense on T2-weighted images. Occasionally, in the presence of intracystic hemorrhage, cysts appear as hyperintense images on T1- and
A direct continuity between the cyst and the disc on sagittal T2-weighted images could be defined in all of the present nonoperative cases, likewise previously reported in the literature ${ }^{(\mathbf{1 7})}$. Atypical presentations also include osteolytic change of the vertebral body adjacent to the cyst ${ }^{(5,18}$ and gas-containing cysts ${ }^{(\mathbf{1 9})}$. The identification of communication of epidural gas collection implicated as a possible cause of radicular symptoms and the disc tissue may also be made by CTD. The vacuum phenomenon has been proposed as the cause of the gas formation ${ }^{(20)}$.

Histological findings of discal cysts include a capsule consisting of dense fibrous connective tissue with no disc material inside ${ }^{(5-7)}$. This finding in association with lack of definitive communication between cyst and disc on MRI T2-weighted sequences is indicative that discal cyst is probably synonymous with ganglion cysts of either posterior longitudinal ligament or annulus fibrosus, and may represent a developmental or degenerative anomaly, with no particular advantage in distinguishing them ${ }^{(21,22)}$. On the other hand, the identification of residual herniated tissue in the cyst wall ${ }^{(\mathbf{1})}$, disc material with myxoid degeneration and apoptosis of chondrocytes in the herniated disc material ${ }^{(\mathbf{1 2})}$, and discal cyst followed by intervertebral disc herniation $^{(8)}$ could be associated with the pathogenesis of the discal cyst, suggesting the hypothesis of focal degeneration.

Postsurgical pseudocysts have been described after laminectomy and lumbar discectomy, and suggested causes include arachnoid hernia through a fissure in the dura mater induced by surgical trauma and persistent spinal fluid or blood leakage leading to the development of pseudomeningocele. A ventral pseudocyst may ossify but usually it contains serous-hemosiderin fluid $^{(2)}$. Postoperative annular pseudocyst is a rare complication of microdiscectomy. Its pathogenesis is probably related to the granulation tissue "pseudocapsule" surrounding the herniated disc that was not disrupted during surgery, creating a potential space where fluid might accumulate by diffusion through the disrupted annulus fibrosus. The increased disc pressure caused by repetitive loading and enlargement of this pseudocyst could cause symp- 
toms ${ }^{(\mathbf{1 0})}$. The first description of a postsurgical intervertebral disc cyst was made by Grabel et al. in $1988^{(9)}$ in a patient with clinical symptoms of failed microdiscectomy. It was interpreted as most likely representing blood breakdown products resulting from surgery. The blood was prevented from escaping into the epidural space probably because the L5 nerve root had tamponated the incised segment of the posterior longitudinal ligament. To the authors' knowledge, cases of double postsurgical annular pseudocysts have never been reported.

Several treatments have been proposed for discal cysts, including surgical resection $^{(\mathbf{5 , 6})}$, fluoroscopy- or CT-guided percutaneous steroid injection ${ }^{(23,24)}$, CT-guided percutaneous aspiration $^{(25)}$ or by percutaneous endoscopic transforaminal approach $^{(26)}$. A case of spontaneous regression of a discal cyst was reported by Chou et al. ${ }^{(27)}$, although the patient has received epidural injection and S1 selective nerve block, both injections containing anesthetic and steroid agents. The authors have felt that is was not clear whether the drugs contributed to the cyst regression, but the steroids could certainly have diffused toward the cyst and caused regression.

\section{CONCLUSION}

Based on the above described cases and on the literature review, it is clear that MRI can easily depict an epidural cyst and that the diagnosis of a discal cyst should be considered in cases where homogeneous ventrolateral epidural cyst contiguous to a partially degenerated disc is identified even if a definitive connection with the annulus fibrosus is not possible in nonsurgical patients or as microdiscectomy complication.

\section{Acknowledgments}

The authors thank Dr. Xavier M. G. R. G. Stump, São Paulo, Brazil, for providing some images for the present study.

\section{REFERENCES}

1. Kobayashi S, Takeno K, Uchida K, et al. Pathogenesis of the discal cysts communicating with an adjacent herniated disc. Histological and ultrastructural studies of two cases. Joint Bone Spine. 2010;77:184-6.

2. Jeong GK, Bendo JA. Lumbar intervertebral disc cyst as a cause of radiculopathy. Spine J. 2003;3: 242-6.

3. Nabeta M, Yoshimoto H, Sato S, et al. Discal cyst of the lumbar spine. Report of five cases. J Neurosurg Spine. 2007;6:85-9.

4. Kornberg M. Nerve root compression by a ganglion cyst of the lumbar annulus fibrosus. A case report. Spine. 1995;20:1633-5.

5. Kono K, Nakamura H, Inoue Y, et al. Intraspinal extradural cysts communicating with adjacent herniated disks: imaging characteristics and possible pathogenesis. AJNR Am J Neuroradiol. 1999;20:1373-7.

6. Chiba K, Toyama Y, Matsumoto M, et al. Intraspinal cyst communicating with the intervertebral disc in the lumbar spine: discal cyst. Spine. 2001; 26:2112-8.

7. Marshman LAG, Benjamin JC, David KM, et al. "Disc cysts" and "posterior longitudinal ligament ganglion cysts": synonymous entities? Report of three cases and literature review. Neurosurgery. 2005;57:E818.

8. Tokunaga M, Aizawa T, Hyodo H, et al. Lumbar discal cyst followed by intervertebral disc herniation: MRI findings of two cases. J Orthop Sci. 2006;11:81-4.

9. Grabel JC, Davis R, Zappulla R. Intervertebral disc space cyst simulating a recurrent herniated nucleus pulposus. Case report. J Neurosurg. 1988; 69:137-9.

10. Young PM, Fenton DS, Czervionke LF. Postoperative annular pseudocyst: report of two cases with an unusual complication after microdiscectomy, and successful treatment by percutaneous aspiration and steroid injection. Spine J. 2009;9: e9-e15.

11. Eerens I, Demaerel P, Haven F, et al. Imaging characteristics of noncontained migrating disc fragment and cyst. Eur Radiol. 2001;11:854-7.

12. Okada K, Saito H, Nishida J, et al. Discal cyst associated with myxoid change and apoptosis of herniated disc materials: a case report. Ups J Med Sci. 2007;112:39-47.

13. Lee HK, Lee DH, Choi CG, et al. Discal cyst of the lumbar spine: MR imaging features. Clin Imaging. 2006;30:326-30.

14. Murata K, Ikenaga M, Tanaka C, et al. Discal cysts of the lumbar spine: a case report. J Orthop Surg. 2007;15:376-9.

15. Norman ER, Beall DP, Kitley CA, et al. Intervertebral disk cyst: a case report. J Comput Assist Tomogr. 2006;30:313-5.

16. Coscia MF, Broshears JR. Lumbar spine intracanalicular discal cysts: two case reports. J Spinal Disord Tech. 2002;15:431-5.

17. Kishen TJ, Shetty AP, Rajasekaran S. Variant of lumbar disc cyst in a 13-year-old girl: a case report. J Orthop Surg (Hong Kong). 2006;14:184 6.

18. Marushima A, Uemura K, Sato N, et al. Osteolytic lumbar discal cyst: case report. Neurol Med Chir (Tokyo). 2008;48:363-6.

19. Kakitsubata Y, Theodorou SJ, Theodorou DJ, et al. Symptomatic epidural gas cyst associated with discal vacuum phenomenon. Spine. 2009;34: E784-9.

20. Pierpaolo L, Luciano M, Fabrizio P, et al. Gascontaining lumbar disc herniation. A case report and review of the literature. Spine. 1993;18: 2533-6.

21. Marshman LAG. Disc cyst. [Letter to the editor]. J Neurosurg Spine. 2007;7:113-4.

22. Marshman LAG. Discal cysts. [Letter to the editor]. J Neurosurg Spine. 2007;7:575-7.

23. Dumay-Levesque T, Souteyrand AC, Michel JL. Steroid injection performed with fluoroscopy for treatment of a discal cyst. [Letter to the editor]. J Rheumatol. 2009;36:1841-3.

24. Koga H, Yone K, Yamamoto T, et al. Percutaneous CT-guided puncture and steroid injection for the treatment of lumbar discal cyst: a case report. Spine. 2003;28:E212-6.

25. Kang H, Liu WC, Lee SH, et al. Midterm results of percutaneous CT-guided aspiration of symptomatic lumbar discal cysts. AJR Am J Roentgenol. 2008;190:W310-4.

26. Kim JS, Choi G, Lee CD, et al. Removal of discal cyst using percutaneous working channel endoscope via transforaminal route. Eur Spine J. 2009;18 Suppl 2:201-5.

27. Chou D, Smith JS, Chin CT. Spontaneous regression of a discal cyst. Case report. J Neurosurg Spine. 2007;6:81-4. 